\title{
Exploring possibilities of the United Nations High Commissioner for Refugees' integration with churches in refugee response
}

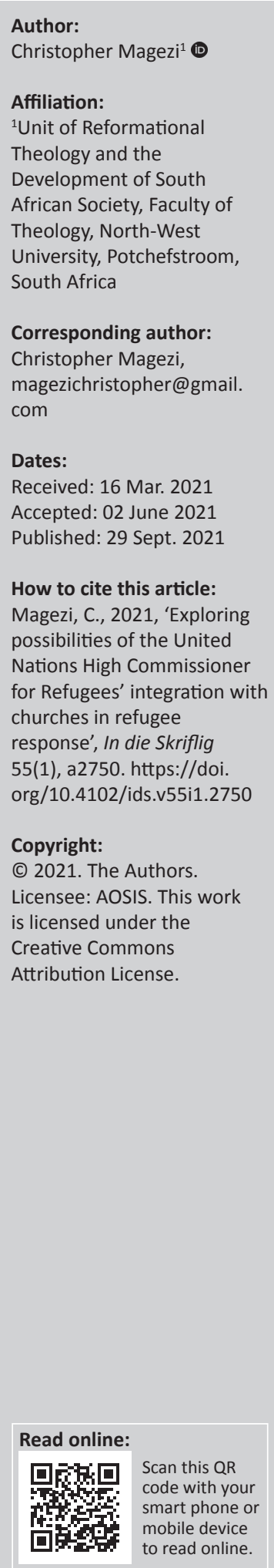

The refugee crisis has been an ongoing global challenge. The United Nations High Commissioner for Refugees (UNHCR) is the international body that is mandated to protect refugees. However, in undertaking its function, it involves many stakeholders such as refugee communities, civil society actors, government entities, non-governmental organisations, other United Nations agencies and the church; thus ensuring effective interventions. With this in mind, it is sought in this article to understand how the UNHCR involved or integrated churches in its approach to intervention in refugee crises, as some churches had evidently become community bulwarks and safe havens for refugees. In order to accomplish the aforementioned objective, literature pertinent to the subject is reviewed. It commenced by discussing the UNHCR's approach to intervention in and responses to the refugee crisis, and this was followed by the identification and discussion of the UNHCR's interventions in which the churches were meaningfully involved to optimise their response to refugee crises. In discussing this role and the approach of the UNHCR, the extent is revealed to which the churches' involvement or integration in the refugee agency's approach to intervention in the refugee crisis was limited. Notably, this limitation was exacerbated by, among many others, the key sticking issues that could be the barriers or challenges in preventing the integration of churches in the UNHCR's responses to migration crises and vice versa. Although there were sticking issues that hampered the UNHCR's integration of churches in its approach to intervention in the refugee crisis, the article is concluded by identifying and discussing some existing opportunities that may further strengthen the existing UNHCR-Church intervention approaches to the crises. Among many others, formal UNHCR-Church collaborations were found to be critical in strengthening their mutual efforts to ameliorate the refugee crisis, as they could complement each other in providing effective and comprehensive interventions.

Contribution: The major contribution of this article is that it examined the responses of the UNHCR and the church to the refugee crisis. Notably, embedded in this was the assessment of how the UNHCR was integrating churches in its approach to intervention in refugee crises. Consequently, this resulted in the identification and discussion of opportunities that may further strengthen the existing UNHCR-Church intervention approaches to the aforementioned humanitarian crisis.

Keywords: United Nations High Commissioner for Refugees; refugees; refugee crises; migration; church; interventions and approaches; UNHCR-Church interventions and approaches.

\section{Introduction}

The United Nations High Commissioner for Refugees (UNHCR) is a United Nations (UN) agency that is mandated to protect refugees, forcibly displaced communities and stateless people, and its interventions include assistance in voluntary repatriation, local integration or resettlement in a third country (United Nations High Commissioner for Refugees [UNHCR] 2011a:1-13). Skeldon (2013:2) and UNHCR (2016a:6) describe refugees as a sub-set of international migrants who are forced to move from their countries by life-threatening crises beyond their control. Gilmore (2016: n.p.), the Deputy High Commissioner for Human Rights, subscribes to the preceding conception when he uses 'migrants in transit' as an umbrella term for all people who do not have citizenship in their hosting countries (Gilmore 2016:n.p). It is important to note that, in performing its function of protecting refugees, the UNHCR involves many stakeholders to ensure effective interventions (UNHCR 2019:1). This is in line with the observation of the World Economic Forum (WEF) (2017:145) that all institutions, government departments and organisations need joint efforts in 
responding to the refugee crisis, because there is no government, institution or organisation that can address its attendant complex challenges alone. In this way, these stakeholders include refugee communities, civil society actors, government entities, non-governmental organisations (NGOs), UN agencies (i.e. United Nations Development Programme) and churches (UNHCR 2019:3).

The question that emerges here is the following: How are the various stakeholders involved and integrated in responding to complex migration issues? Of particular interest in this discussion is how the UNHCR involves or integrates churches in its approach to intervention, as some churches have evidently become community bulwarks and safe havens in refugee crises (Goodall 2015:17-18; Magezi 2018:284). In view of this recognition, it is imperative to understand how the UNHCR is working with churches as critically committed community players in refugee crises interventions. Given this, the purpose of this article is to establish the nature of integrated interventions that could be explored to optimise the role played by the churches within the UNHCR response system. In order to accomplish the above-mentioned objective, this article will provide a global survey of the UNHCR integration of churches in responding to migration challenges. I am aware that some schools of thought prefer that the author would focus on a particular context, for instance refugees in Southern Africa rather than attempt a global survey, as it would allow a more in-depth analysis, complemented by a sharper theological dimension. Nonetheless, whilst I acknowledge the validity of the aforesaid argument, I am of the opinion that a global survey of the UNHCR integration with churches would assist the author to identify possible informed solutions relevant to different contexts.

In the initial section, the UNHCR's approach to intervention and response will be discussed. The second section will seek to identify and discuss the UNHCR's interventions that meaningfully involve churches in optimising its roles in responding to refugee crises. The final section will determine if there are any UNHCR and church integrated interventions that could be explored to optimise the role played by the churches within the UNHCR's response system to refugee crises. Once that is done, the article will be concluded by highlighting the overarching findings.

\section{The United Nations High Commissioner for Refugee's approach to intervention to refugee crises}

\section{Addressing the root causes of migration}

The UN believes that the most effective intervention for reducing mass global migration is that governments and NGOs should work together in addressing its root causes (UN 2016:14). This arises from the conception that, whilst people have the right to migrate to other countries for safety, especially when deprived of their rights in their countries of origin, it is also true that they have rights to live in their home countries. International communities have a responsibility to ensure that people are not forced to abandon their homes and communities to survive or in search of safety (UN 2016:14). This notion is corroborated by many migration scholars such as Carling and Tallerra (2016:1-40) and Mckeon (2018:1-16) who call for all stakeholders to address the root causes of migration. These scholars propound that, as long as the push and pull factors of migration exist, many countries will continue to face an influx of migrants, particularly refugees. In view of the rampant Syrian refugee crisis in Europe, the UN urges national governments to adopt humane resettlement programmes and address the primary causes of migration (Grandi 2016:n.p).

The UN (2016:14) is cognisant of what is needed to address the causes of the movement of large numbers of people across international borders. Instead of the governments preventing the influx of refugees into their countries by tightening entry restrictions, they need to mobilise political will and effort to meet the:

\footnotetext{
... sustainable development goals and targets of the 2030 agenda for sustainable development [which] would reduce the need for migrants to leave their homes in search of greater opportunities by addressing some of the root causes of involuntary movements of refugees and migrants. (UN 2016:3)
}

Further, this would also provide 'well managed migration policies, lower the costs of migration, and strengthen the contribution of migrants and refugees to countries of origin and destination alike' (UN 2016:13).

Now, the underlying question is as follows: What is the UNHCR, as the international body or UN agency that is mandated to protect refugees, doing to address the root causes of the forcible displacement of people across the globe? In order to understand this, one need to examine what the UNHCR is doing to address the root causes of the Syrian refugee crisis, which it regards as the biggest mass displacement of our time demanding a huge surge in solidarity (UNHCR 2016b). The Arab-Syrian conflict was the major factor that accounted for the unprecedented increase of internal and international refugees between 2011 and 2015 (UNHCR 2015:6, 13; 2017:3; 2018a:n.p). Further, the UNHCR (2018b) indicates that over 5.6 million Syrians left Syria between 2011 and 2018 to seek safety in countries such as Lebanon, Turkey, Jordan and beyond (UNHCR 2018b:n.p). Thus, in examining the interventions that the UNHCR implemented in addressing the root causes of refugee crises, the Syrian case suffices as a productive approach, as it has been the leading refugee crisis for a considerably long time (UNHCR 2018b:n.p).

Notably, the UNHCR concedes that it addresses the symptoms rather than the root causes of the Syrian refugee crisis. Filippo Grandi, the High Commissioner of Refugees of UNHCR, argues that the current approache to peace making are fragmented, as it only addresses the symptoms instead of 
the root causes of forced migrations (UN 2019: n.p.). In saying this, Filippo Grandi calls on the United Nations Security Council to resolve conflicts and security issues that cause many refugee flows, as well as to support the hosting countries and to remove the obstacles that hinder reception (UN 2019: n.p.). Given the aforementioned call, one can argue that the UNHCR acknowledges the importance of addressing the root causes of mass migrations. However, it is only addressing the symptoms (UNHCR 2016a:6).

\section{Advocating the human rights of migrants in transit}

The UN (2016:14) advocates the human rights of migrants, both in transit and upon arrival in hosting nations, by calling all nations to respond to all refugee movements 'with full respect of international human rights, refugee, humanitarian and labour law'. This call arises from the migration laws which indicate that all people in transit are entitled to protection, regardless of whether they are refugees, asylumseekers or migrants (UN 2016:14-15). In reference to the prolonged Syrian refugee crisis, the Working Groups for the Syrian Situation (2019:4) note that the UNHCR requires all governments, institutions and organisations to offer assistance and protection to all people who are prone to losing their lives at sea. This assistance should be in the form of a coordinated response by all member states of the 1951 Convention of Refugees and other international laws of migration (Working Groups for the Syria Situation 2019:1). All the member states are obligated to disrupt smuggling and trafficking networks, and apprehend and prosecute the criminals who profit from activities that endanger the lives of migrants, particularly refugees (Working Groups for the Syria Situation 2019:1).

Further, the UNHCR calls on member states to address the physical and emotional or psychological dangers faced by the migrants, particularly refugees in transit, regardless of their status and the forms of transport they use (UN 2016:16). The UNHCR urges governments to refer refugees whose needs are beyond their jurisdictions and capacity to relevant institutions and organisations (UN 2016:16). However, with the current global pandemic, Covid-19, Filippo Grandi warns nations not to violate the core principles of refugee protection (UNHCR 2020). Grandi states that the Covid-19 pandemic has put nations' commitment to refugee protection principles to the test, because people who are forced to 'flee conflict and persecution should not be denied safety and protection on the pretext, or even as a side effect, of responding to the virus' (UNHCR 2020).

However, the UNHCR estimates that, in order to contain the spread of the pandemic, 167 nations have fully or partially closed their borders (UNHCR 2020). These measures are being done at the expense of the international conventions that oblige countries to allow entry to all the people who are fleeing from persecution, violation of human rights and conflict. In the cotemporary context of the deadly Covid-19 pandemic, the UNHCR continues to firmly challenge countries to remain faithful to their commitments to the international conventions of migration.

\section{The United Nations High Commissioner for Refugee's durable solutions for refugees}

\section{Voluntary repatriation}

The UNHCR supports the:

$[V]$ oluntary and sustainable repatriation of refugees in safety and dignity to their places of origin or choices, and it works with all parties to achieve the repatriation of refugees in safety and dignity. (UNHCR 2018b: n.p; cf. UNHCR 2011b:28, Working Groups for the Syrian Situation 2019:8)

Notably, the repatriation of refugees is premised on their free and informed decisions, as well as relevant and reliable knowledge of the existing conditions in their countries of origin and preferred areas of repatriation after the unstable period (UNHCR 2011b:24).

Although refugees have their own means of accessing information about the existing conditions in their countries of origin, the UNHCR works with various interagency communities and institutions to get that information (UNHCR 2018b: n.p.). For instance, whilst Syrian refugees have their own sources of information about the situation inside Syria, the interagency aid communities and the UNHCR, in particular, have a responsibility to provide objective and detailed information which is responsive to refugees' questions and needs for informed decision-making (Working Groups for the Syrian Situation 2019:12).

That is, in preparation for the voluntary repatriation of Syrian refugees, the UNHCR focuses on ensuring that they have access to 'objective information on the conditions inside Syria' (Working Groups for the Syrian Situation 2019:8). However, the UNHCR has limited access to Syria, which consequently limits its ability to provide Syrian refugees with detailed, relevant and reliable information that could help them to make informed decisions on voluntary repatriation (Working Groups for the Syrian Situation 2019:8). Thus, to ensure genuine voluntary repatriation for refugees, the UNHCR conducts critical activities such as voluntary assessments to ensure that the refugees are provided with unbiased information that assists them to make free and informed decisions regarding their repatriation (Working Groups for the Syrian Situation 2019:8). In other cases, the UNHCR allows the refugees to visit their places of origin (i.e. as happened with Bangladeshi refugees), so that they can see for themselves if the conditions have improved enough to warrant returning home (UNHCR 2018b: n.p.).

Nevertheless, the UNHCR (2018b: n.p) holds that the responsibility to improve the conditions in the refugees' countries of origin lies with their governments. However, due to its central responsibilities to secure, protect and assist voluntary returnees, the UNHCR is always committed to supporting governments to improve local conditions 
(UNHCR 2011b:24). In other words, the UNHCR has an important capacity-building role, offering training programmes, infrastructure development and material support to the concerned governments (UNHCR 2011b:24). Important to note is that 'where there are indications or evidence that the freedom or security of returnees is at risk, [the] UNHCR ... does not promote further repatriation until the problems are rectified' (UNHCR 2011b:24).

However, the UNHCR assists refugees who are willing to return to their countries of origin with 'non-discriminatory provision and access to protection services, accessible and affordable civil documentation, and targeted assistance for individuals with specific needs' (Working Groups for the Syrian Situation 2019:8). Given that the Syrian situation is the worst contemporary humanitarian and displacement crisis, the UNHCR has repatriated 56000 Syrian refugees (UNHCR 2019:1). Indeed, this shows that the UNHCR intervenes in contemporary refugee crises by ensuring safe, dignified and voluntary repatriation.

\section{Local integration}

The UNHCR (2011b:28) also assists refugees to integrate in the communities and employment sectors of host countries. Local integration is 'when refugees legally, economically and socially integrate in the host country, availing themselves of the national protection of the host government' (UNHCR 2011b). Fielden (2008:1) and Jacobsen (2001:11) note that local integration, as a solution for refugee dilemmas across the globe, receives little attention from host countries because of its attendant security and financial concerns. Instead, most governments pay more attention to voluntary repatriation as a solution to the global refugee plight (UNHCR 2011b). However, there is need to shed more light on the notion of refugee integration, which works in three aspects, namely the integration of returnees in their countries of origin, the integration of refugees in their resettlement country, and the integration of refugees in their first country of asylum (UNHCR 2011b).

The integration of refugees in their first country of asylum has three dimensions as Fielden (2008) demonstrates:

Firstly, it is a legal process, whereby refugees attain a wider range of rights in the host state. Secondly, it is an economic process of establishing sustainable livelihoods and a standard of living comparable to the host community. Thirdly, it is a social and cultural process of adaptation and acceptance that enables the refugees to contribute to the social life of the host country and live without fear of discrimination. (p. 2)

To date, the UNHCR has facilitated local integration of many refugees. In evaluating its Emergency Response to the influx of Syrian refugees into Turkey, the UNHCR (2016a:61) notes that Turkey does not use Arabic as a language of instruction and communication. To assist the Arabic-speaking Syrian refugees with integration within Turkey:

[The UNHCR] place[s] a major emphasis on supporting Syrian children to access Turkish schools by supporting the legal and policy changes to facilitate access, and by providing Turkish language training to students, material assistance for Turkish schools, as well as guidance and support to Turkish teachers who are in some cases struggling to provide services to Syrian student. (p. 61)

The UNHCR (2016a:61) offers two prolonged approaches in Syria, namely the emergency response that provides immediate education opportunities and safe learning spaces for refugees and the promotion of medium- to long-term education policies and strategies upon which Syrian education will be built. In partnership with the United Nations Children Fund (UNICEF) and other related organisations, the UNHCR advocates several changes by the Turkish government (UNHCR 2016a:62). The UNHCR also advocates the regularisation of the Syrian curriculum in order to make it accessible to Syrian children aged 6-17 (UNHCR 2016a:62). These efforts demonstrate how the UNHCR uses integration as one of its intervention measures for addressing refugee challenges.

\section{Resettlement of refugees to a third country}

The UNHCR considers the resettlement of refugees to a third country as a vital international protection intervention for refugees (UNHCR 2011b:28, 47). In the view of the UNHCR (2011b:28), resettlement is 'when refugees are selected and transferred from the country of refuge to a third state which has agreed to admit them as refugees with permanent residence status'. Resettlement is also a 'principal or partial durable solution for refugees that was immensely used to address people that were internally and internationally displaced during the First and Second World Wars' (UNHCR 2011b:47). The UNHCR (2018b) tacitly notes that the 'resettlement states provide the refugees with legal and physical protection, including access to civil, economic, social and cultural rights similar to those enjoyed by nationals'. Notably, the United Nations' predecessor, the League of Nations, used resettlement as a vital means of addressing the challenges of internally and internationally displaced people (UNHCR 2011b:47).

In 1945, when the UN replaced the League of Nations, it created the International Refugee Organisation (IRO), which came into being in 1946 (UNHCR 2011b:47). The responsibility of the IRO was to particularly protect the refugees that were scattered across Europe after the Second World War (UNHCR 2011b). Although the IRO's initial objective was to facilitate voluntary repatriation, it also resettled those refugees that had valid reasons, such as persecution, conflict and violation of human rights, not to return to their countries of origin (UNHCR 2011b). From 1947 to 1952, the IRO resettled over 1 million refugees, and repatriated more than 73000 of them to their countries of origin (UNHCR 2011b). Thereafter, the IRO was replaced by the Office of the United Nations High Commissioner for Refugees (OUNHCR), which continued to utilise resettlement to address the global refugee challenge (UNHCR 2011b:47, 48). The OUNHCR conducted some notably large resettlements as indicated below: 
The Soviet invasion of Hungary in 1956 caused 200,000 refugees to flee to Yugoslavia and Austria, many of whom were later resettled in other countries. In 1972, most of its Asian minority were expelled from Uganda. With the help of [the] OUNHCR, the International Organization for Migration (IOM), the International Committee of the Red Cross (ICRC), and the United Nations Development Programme (UNDP), some 40,000 Ugandan Asians were resettled within a few months to 25 countries. (pp. 47-48)

It is important to note that, from 1986, there was a shift from resettlement to repatriation (UNHCR 2011b:48). Due to the deterioration of human rights and adverse economic factors in Vietnam, the UNHCR (2011b:48) reported an increase in the number of people who left Vietnam in the hope of resettling in other countries. At the beginning of 1986, the number of people who arrived by boat in first-asylum countries of South East Asia rose from 31694 to 65349 (UNHCR 2011b:48). To reduce the number of refugees leaving Vietnam for South-East Asian countries, and hoping to benefit from UNHCR's resettlement policy, the UNHCR introduced a Comprehensive Plan of Action (CPA), which was aimed at addressing the arising global challenge in a systematic manner (UNHCR 2011b:48). Among many other things, the CPA thoroughly screened the Vietnamese refugees when they landed in their first-asylum countries for refugee status, and those who qualified, were later resettled in third countries (UNHCR 2011b:48). Those that did not qualify for refugee status were repatriated back to Vietnam, and interventions, such as reunification with families, were encouraged (UNHCR 2011b:48).

To date, the UNHCR still uses resettlement as an intervention measure to refugee crises, albeit at a lower rate (UNHCR 2018a). The UNHCR (2018a) states that, in 2018, there were 20.4 million refugees of concern. However, less than $1 \%$ of them are resettled every year. There are very few states, such as the United States of America, Canada, Germany, United Kingdom, Australia and the Nordic countries, that participate in the UNHCR's resettlement programme (UNHCR 2018a). In 2019, the UNHCR submitted files of more than 81600 refugees intending to be resettled to the aforementioned countries (UNHCR 2018a). Of these refugees, 29700 were from the Syrian Arab Republic, followed by 19000 from the Democratic Republic of Congo, 5900 from Afghanistan and 4400 from Somalia (UNHCR 2018a). Of the 81600 refugees, 63600 departed to countries of resettlement with the UNHCR's assistance (UNHCR 2018a).

Although resettlement is a challenging solution for refugees, as they are often resettled in countries that have different languages and cultures, it is apparent that the UNHCR uses it as a vital intervention to address the global refugee problem.

\section{Facilitating self-reliance for refugees}

The UNHCR facilitates for refugees to be self-reliant instead of being dependent on the UNHCR and other stakeholders (UNHCR 2011b:29). The UNHCR does not consider selfreliance as an important precursor to the aforementioned durable refugee solutions (UNHCR 2011b:29). The UNHCR (2011b:29; cf. UNHCR 2009) defines self-reliance as:

Social and economic ability of an individual, a household or a community to meet essential needs (including protection, food, water, shelter, personal safety, health and education) in a sustainable manner and with dignity. As a programme approach, self-reliance refers to developing and strengthening livelihoods of persons of concern in an effort to reduce their vulnerability and long-term reliance on humanitarian and external assistance. (p. 188)

Through various means, such as 'income generating, agricultural or community development projects', the UNHCR and its NGO partners seek to increase the capacity of refugees to be self-reliant upon arrival in countries of asylum (UNHCR 2011b:29). The UNHCR also offers the refugees other services such as 'education, micro-financing, language courses, vocational training, and access to adequate accommodation and social services'. The aforementioned initiatives benefit both refugees and local communities; thus, positioning refugees as agents of development (UNHCR 2011b:29). For instance, with regard to the Syrian refugee crisis, the UNHCR and its implementing partners provide skills training (i.e. sewing) to the Syrians in refugee camps in Turkey so as to enhance their employment opportunities and self-reliance (UNHCR 2015:64). Further, among many other things, given the importance of tertiary education in enhancing people's capacities and creating job opportunities, the UNHCR provided 1000 full scholarships to Syrian refugees and persuaded the Turkish government to waive tertiary education tuition fees for Syrian students.

The self-reliance interventions are offered prior to the recognition of refugee status and pending the identification of a durable solution (UNHCR 2011b:29). The interventions are crucial in the following ways: (1) they reduce the burden on the countries of asylum as fewer refugees will be dependent on the host countries' assistance; (2) they give the refugees hope, dignity, confidence and autonomy; and (3) they provide the basis for sustainable and durable solutions, as refugees who actively support themselves are better equipped to take on the challenges of voluntary repatriation, resettlement, or local integration (UNHCR 2011b:29).

Thus, one can argue that the UNHCR promotes self-reliance activities for refugees, which consequently alleviate the burden on host countries and promote the refugees' sense of self-worth in many ways, as they will be able to meet their basic needs on their own.

\section{Provision of material needs}

The UNHCR provides material support to refugees. For instance, the 2019 Update of the UNHCR Response to the Syrian refugee crisis indicated that, despite its operational challenges in the Syrian Arab Republic, the UNHCR (2019) had reached over 2 million refugees with protection services: 
[The UNHCR reached] more than 250,000 with shelter support; almost 1.9 million with basic relief items; and some 390,000 with health assistance (all figures as of November 2018). In addition, over 400,000 people were reached with basic relief items and shelter support through cross-border interventions from Jordan and Turkey. (p. 1)

This kind of support is needed, because over $50 \%$ of Syrian refugees are exposed to precarious living conditions in some host countries (UNHCR 2019:1). However, this does not necessarily mean that the host countries are not providing support for the refugees. In many host countries, refugees have access to health, education and legal services. There is, however, need for the international community to also ensure that refugees are effectively and comprehensively supported and protected (UNHCR 2019:1). In terms of financial support, the UNHCR (2019):

\begin{abstract}
... transfers cash to some 70,000 refugee households (around 450,000 individuals) each month, while additional families benefit from its cash coordination mechanisms with partners. The 2018 winter programme has reached some 2.5 million Syrians and Iraqis, mostly through multi-purpose cash transfers. (p. 2)
\end{abstract}

This illustrates that the UNHCR provides refugees with basic material and financial support.

\section{Advocating refugees' access to asylum}

UNHCR (2019:1) reports that the UNHCR advocates asylum for refugees, which intensifies through the expansion of its international responsibility in sharing the burden of refugee care with hosting countries (UNHCR 2019). For instance, in Egypt where 242900 refugees and asylum-seekers from 65 countries are registered with UNHCR, some progress was made to include refugee children in the national education system (UNHCR 2019:2). As a result of the UNHCR's advocacy silent of the adoption of national asylum laws, the Mauritanian government began issuing national identity cards for over 57000 Malian refugees in the Mbera camp. In Morocco, the UNHCR (2019):

.. [S]igned a memorandum of understanding with the national employment agency and the Office for the Development of Cooperation to support livelihood opportunities for refugees. (p. 3).

This illustrates that the UNHCR intervenes in refugee crises by advocating the granting of asylum seeker status to refugees. However, some obstacles are encountered, because, for security and cultural reasons, some countries are reluctant to offer asylum to refugees (Fielden 2008:1; Jacobsen 2001:11).

\section{The office of the United Nations High Commissioner for Refugee's interventions that optimise the church's role in responding to refugee crises}

Given the above-mentioned UNHCR interventions for addressing the refugee crises, in this section it is sought to identify and discuss the UNHCR's interventions that meaningfully involve churches in optimising their response to refugee crises.

\section{Advocating for the human rights of refugees}

Just like the UNHCR, the churches are also involved in advocating the rights of migrants, particularly refugees. Due to the influx of Syrian refugees into Europe in 2015, Press Release No. 15/35 (2015), and Jackson and Passarelli (2016:101-107) indicate that many European churches are involved in advocacy of the asylum and human rights of refugees. These churches include the following: the Federation of Churches in Australia, the United Protestant Church in Belgium, the Czechoslovak Hussite Church, the Evangelical Lutheran Church of Denmark (ELKD), the Evangelical Lutheran Church of Finland (ELCF), the Evangelical Church in Germany, the Church of Greece (Orthodox), the Lutheran Church of Iceland, and the Methodist Church (Republic of Ireland) (Jackson \& Passarelli 2016). For instance, the Presbyterian Church in Ireland does its advocacy work in conjunction with the Irish Council of Churches, the World Communities of Reformed Churches, the Irish Inter $\square$ Church Meeting and the Conference of European Churches (CEC), whilst the Church of Greece (Orthodox) works with the Integration Centre for Working Migrants, commonly known as the KSPM $\square$ ERP (Jackson \& Passarelli 2016:106-108).

The Integration Centre for Working Migrants is an NGO for the churches in Greece, which works with other European and international entities that defend the human rights of migrants, particularly refugees (Jackson \& Passarelli 2016:106). However, the church's response to the refugee crisis in Europe is undergirded by intra-church organisations such as the World Council of Churches (WCC), the CEC and the Churches' Commission for Migrants in Europe. For instance, in response to the Syrian refugee crisis in Europe, on 10 September 2015 the WCC, the CEC and the Churches' Commission for Migrants in Europe released a joint letter calling on all their member churches to double their efforts in receiving, supporting and protecting refugees in their respective regions (Press Release No. 15/35 2015). These intra-church organisations advocate a Common European Asylum System that includes decent reception conditions for refugees, as well as a common European Resettlement scheme that puts human dignity at the centre of the process (Press Release No. 15/35 2015). This entails lobbying the European governments to take care of the refugees who usually do not have access to health care and education upon arrival (Press Release No. 15/35 2015).

In the South African context, Magezi (2018:278-281) reveals that some churches in South Africa are doing a lot of work in advocating the human rights of migrants, particularly refugees. Some South African churches assist refugees through the asylum application process by giving them money for transport to the asylum offices in Pretoria, as well as working with human rights lawyers to challenge unfounded asylum application rejections (Magezi 2018). 
However, the South African Church's response is hampered by lack of finance and limited understanding of the underlying legal procedures involved in applying for legal documentation for refugees (Magezi 2018:281-282). Notably, all these challenges, faced by the South African churches when addressing the legal documentation issues of the refugees, highlight the poor UNHCR-Church integration when intervening in refugee crises. In my view, the church's role in addressing the issue of refugees' documentation could be strengthened through collaboration with the UNHCR, which has expertise in executing the asylum application processes. Also, the church often has limited financial resources, whilst the UNHCR is better resourced to handle these issues. With the UNHCR's support, the church may intervene more effectively in assisting refugees to obtain asylum. Unfortunately, it seems that the church is seeking to integrate the UNHCR in its intervention efforts, instead of it being the other way round.

For instance, at its 10th conference, the WCC collaborated with the Bread of the World to organise a conference, which was later held in Germany on 05 and 06 September 2017 (WCC 2017). This conference, which was attended by 25 representatives from faith-based and church organisations, civil society and the UNHCR, focused on addressing the needs of vulnerable refugees who are considered stateless in the European context (WCC 2017). The Germany conference was one of the many regional-focused conventions held by the WCC where relevant stakeholders positively responded to refugee challenges (WCC 2017). In a nutshell, the purpose was to influence European people and governments to adopt humane approaches towards refugee protection in line with the relevant European and international conventions.

These approaches include the facilitation of legal and secure access to Europe for those in need of protection (Press Release No. 15/35 2015). Here, it is evident that the church was attempting to integrate the UNHCR in its interventions, instead of the UNHCR taking the lead, as it is the international body or UN agency that is mandated to protect refugees, forcibly displaced communities, and stateless people (UNHCR 2011b).

\section{The church's involvement in refugee resettlement}

From the lens of the Protestant Church in America ${ }^{1}$, particularly the role played by the Methodist Church in refugee resettlement programmes during and after the Cold War, Chiba (2016) notes that:

While the state role was imperative in creating a legislative framework, church groups played a leading part in arranging and implementing resettlement, frequently lobbying and negotiating with government. (p. 70)

1.Here, the author is jumping between different historical periods of the church's re the the migration crisis, because he is giving a global survey. The response to the migration crisis, because he is giving a global survey. The author acknowledges that it would be legitimate to give a short report on the churches involvement in refugee resettlement in different places and times. However, this would fall outside the scope of this article.
Unfortunately, Chiba (2016) does not elaborate on how the church was involved in the resettlement programmes. However, it is important to note that the International Catholic Migration Commission (ICMC), an international organisation of the Roman Catholic Church has done a lot of work in the resettlement of refugees (ICMC/ProAsyl 2013:n.p). The ICMC was created in 1951 as a special church agency for serving and protecting migrants, refugees and internally displaced people regardless of their faith, race, ethnicity or nationality (ICMC/ ProAsyl 2013:n.p).

Since its formation, the commission has identified and resettled over 1 million refugees. It also provides the UNHCR with expert fieldwork personnel through its ICMC-UNHCR Deployment scheme (ICMC/ProAsyl 2013:n.p). The ICMC offices in Turkey and Lebanon have been effectively responding to the Syrian refugee crisis (ICMC/ProAsyl 2013:n.p). Through these offices, the ICMC Refugee Support Centre processed many refugees for resettlement in the United States of America, and the Brussels office, in partnership with the International Organisation for Migration (IOM) (2015) and the UNHCR, has been working earnestly to promote the effective resettlement of refugees across Europe (ICMC/ProAsyl 2013:n.p).

Although the ICMC's collaboration with the UNHCR is noted and commendable, it is unfortunate that some European church efforts to participate in the resettlement schemes of the UNHCR never materialised due to lack of support by the UNHCR itself. For instance, in responding to the Syrian conflict as the current leading humanitarian crisis, in 2015, 84 Anglican Church leaders (including all four Bishops in the Diocese) petitioned the government of the United Kingdom (UK) to increase its refugee resettlement scheme by accepting a minimum of 50000 refugees for resettlement in the UK (Diocese of Southwark 2015:n.p). The Anglican Church pledged support in settling newly arrived refugees (Diocese of Southwark 2015:n.p). Unfortunately, the church leaders' plea was dismissed by the UK government. However, the church remained committed to supporting the government's commitment to resolve the refugee crisis in Europe and beyond (Diocese of Southwark 2015:n.p).

The Berkley Forum (2018:n.p) notes that American churches have been involved in the resettling of refugees in Europe. However, it does not stipulate the nature of their involvement. Reporting on a survey by the Public Religion Research Group in America, which reveals the anti-refugee spirit among Christians, the Berkley Forum (2018) states that:

The Public Religion Research Group found that 31 percent of Americans favour passing a law that would prevent refugees from coming to the United States. Among Christians, 45 percent of white mainline Protestants, 44 percent of Catholics, and 44 percent of white evangelical Protestants support banning refugees, though only 37 percent of non-white Protestants felt similarly. (n.p)

Whilst there is lack of UNHCR-Church collaboration in refugee resettlement schemes, it is apparent that there is an existing anti-migrant spirit among American Christians, which 
hampers their involvement in the UNHCR's intervention programmes. In substantiation, Soerens, the author of Seeking refuge on the shores of refugee crisis, gave a stimulating informative presentation on migration at the churches responding to the Global Refugee Crisis seminar in Twin Cities, which was attended by 170 members (Arrive Ministries n.d.).

Soerens revealed that $86 \%$ of US Protestant pastors were of the conviction that Christians should care for refugees in a sacrificial manner. However, only $8 \%$ of them were involved in responding to refugees' needs. Indeed, this demonstrates that few churches are involved in the UNHCR's intervention to resettle refugees. It also seems that there is more rhetoric in the churches than practical service and support for the UNHCR's interventions, as very few pastors are involved in responding to migrants' needs.

Taking all this into account, I posit that the apparent lack of church involvement in the UNHCR's resettlement programmes is exacerbated by the lack of will and effort shown by the governments as highlighted by the abovementioned dismissal of the UK Anglican Church leaders' request. This also shows that national governments are likely to participate more positively in refugee resettlement schemes when the church and the UNHCR work collaboratively.

\section{Providing material needs for migrants such as food and accommodation}

Jackson and Passarelli (2016) and Magezi (2018:284, 289-291) highlight that many churches offer material support, such as food and clothes, to migrants, particularly refugees. Many European churches, such as the United Protestant Church in Belgium, the Church of Cyprus (Orthodox), the Czechoslovak Hussite Church, the ELKD, the ELCF and the Methodist Church in the Republic of Ireland, offer migrants food parcels and clothes (Jackson \& Passarelli 2016). Likewise, in the South African context, some churches provide meals and food parcels to destitute refugees (Magezi 2018:284, 289-291). Together with Jackson and Passarelli (2016), I argue that the provision of this kind of material support to refugees is crucial. Many of the refugees take time to settle down or get employment in their host countries due to lack of legal documentation and other obstacles hindering them from accessing basic services and needs.

The provision of food to refugees is critical as spelt out by Olav Fykse Tveit, the General Secretary of the WCC. In a meeting with the business and political leaders who gathered in advance of the WEF in Switzerland in 2016, Tveit spelt out what came to be known as the 10 commandments of food aid (Bread for the World 2016: n.p.). He called on the various organisations to view food through the lens of social justice in which all human beings, including refugees, need it to keep their human dignity (Bread for the World 2016: n.p.). In other words, 'food is sacred, as it is a gift from God to sustain our lives through sharing' with those that do not have such as vulnerable refugees (Bread for the World 2016: n.p.). Tveit challenged the WEF delegates to work together to address climate-change challenges and other barriers that threaten global food security (Bread for the World 2016: n.p.).

In Migration and migrant workers: Discerning responses as churches, the WCC (2011:n.p) indicates the rapid increment of the number of refugees, especially women, who become homeless in hosting countries. The document examines the migration situation of South East Asia, South Asia, the Middle East and Gulf Regions, and concludes that migrant workers experience immense emotional and psychological trauma because of being away from their families and the sub-human living conditions that they end up in (WCC 2011: n.p). Notably, $55 \%$ of Asian migrant workers are women, most of whom:

$[A]$ re often exposed to sexual abuse and harassment, harsh treatment, and made to work long hours without any rest, health care and with little or no contact with anyone outside their work places. (WCC 2011: n.p.)

These women and many other vulnerable migrants are usually in great need of support. In order to mitigate the trauma experienced by the refugees in distress, some churches run shelter homes that provide counselling and other relevant forms of support (WCC 2011: n.p.). Some churches in Gauteng, South Africa, provide accommodation for homeless sick refugees and, if they die there, they are given a proper burial (Magezi 2018:284).

However, due to financial constraints, some churches cannot afford to offer shelter facilities, resulting in individual congregants resorting to accommodating the desperate refugees in their private homes (Goodall 2015:17-18). Goodall (2015:17-18) also notes that a number of financially constrained churches resort to using their church buildings as sanctuaries for vulnerable migrants, some of whom are on the brink of being deported, inadvertently breaking state laws in doing so. Consequently, some of these churches are raided by the police who arrest and facilitate the deportation of all illegal migrants in spite of the intervention of the churches (Goodall 2015). However, despite the aforementioned constraints experienced by the churches in addressing the material needs of refugees in church and non-church spaces, it is ostensible that they prioritise the provision of material support to refugees (Goodall 2015:17-18; Magezi 2018:284, 289-291). Therefore, there is a need for churches to collaborate with the UNHCR to realise the comprehensiveness and effectiveness of the interventions in refugee crises.

\section{Local integration of migrants and upskilling of refugees}

Stromberg (2003:48), Jackson and Passarelli (20162), Adele (2012:408-414) and Magezi (2018:285-286, 291-293) state that many European churches integrate refugees in their churches through multicultural worship. Nzayabino (2010), Kuzituka (2009) and Prill (2009:332) view multicultural worship as critical, as culture and language are major barriers to the integration of migrants, particularly refugees, into local 
churches. Multicultural worship entails people from different culture and linguistic backgrounds worshipping God in their cultural and linguistic ways as people from different cultural groups interact with God in different ways (Prill 2009:332). This approach is regarded as progressive (Prill 2009:332), although congregations seem to 'be divided by racial, national and tribal or linguistic identities' (Kwinyani 2018:15).

However, although multicultural worship is a commendable way of addressing language and cultural barriers in churches, it deprives refugees of opportunities to learn the native languages and, consequently, upskill themselves in order to increase their chances of getting employment (Jackson \& Passarelli 2016; Omidvar 2016: n.p.). Likewise, Magezi $(2018: 285,288)$ notes a lack of migrant integration in some South African churches, as only a few of them have taken it upon themselves to teach the refugees native languages or life and entrepreneurial skills. I argue that multicultural worship is problematic, as it does not offer migrant and native congregants a platform for mutually beneficial interaction. This is buttressed by Mallows' assertion (2014) that:

Basic knowledge of the host society's language, history and institutions is indispensable to integration; enabling immigrants to acquire this basic knowledge is essential to successful integration. (p. 2)

Likewise, in research titled 'What drives the language proficiency of immigrants? Immigrants differ in their language proficiency along a range of characteristics', Isphording (2015:1) argues that 'language proficiency is a key driver of immigrant integrations. It increases job opportunities and facilitates social and political participation.' Those refugees who fail to achieve adequate proficiency in the host country's language, generally fail to achieve economic and social integration (Isphording 2015:1). In the context of this discussion, it does not matter whose responsibility it is to teach the refugees the languages of the host countries. Instead, as Terfassa (2016) notes:

[What matters are that the] challenges we face in relation to integration are too big to be solved by a single church or society. They call for a change of attitude by every one of us. We need to avoid prejudices which have built walls of separation and to recognise one another as members of the same family. (p. 189)

Thus, in heeding Terfassa's call (2016), I argue that churches can take it upon themselves to teach local languages to the refugees so that they can be integrated in all sectors of their host countries. However, it is regrettable that the current approach to integration is narrowly focused, as they only emphasise separate worship services. However, although many churches have limited financial resources to address the complex material needs of migrants (Kwinyani 2018:14-17; Magezi 2018:289-291), I argue that starting language classes for migrants would suffice as a productive approach that would relieve the churches of the burden of care for refugees, as those learning native languages, would be able to upskill themselves and work to earn enough money to sustain themselves. Although a complex and costly approach, it gives the churches leverage to utilise their limited resources to take care of newly arrived migrants, particularly refugees.

It is unfortunate that the UNHCR and the church do not effectively involve one another in their respective integration interventions. Thus, there is need for integrated UNHCR Church interventions, because the church plays a critical role in facilitating the care and integration of refugees in the local communities of host countries (Stark 1996). On the other hand, the UNHCR, as the leading refugee agency of the UN, can help the churches with the requisite human and financial resources for teaching the refugees the cultures and languages of the host countries, as well as upskilling them to be self-reliant.

\section{Call to address the root causes of migration}

Like the UNHCR, the WCC also responds to migration crises by calling on migrant-sending countries to address the root causes of involuntary migration, which include persecution, wars, political instabilities and natural disasters (i.e. famine and climate change) (Terfassa 2016:191; WCC 2017: n.p.). Usually, involuntary migrants are forced to leave their countries of origin without acquiring the requisite legal documents, as they do not have enough time to prepare for their migration. They are rendered stateless on arrival in host countries (Terfassa 2016:191; WCC 2017:n.p).

Therefore, refugees can be subjected to different forms of exploitation and discrimination, such as being barred from accessing health and education services (Terfassa 2016:192). The WCC believes that migration inflows to economically and politically stable nations can be reduced by addressing the push factors (WCC 2016: n.p.).

In reacting to the deaths of many African migrants on the Mediterranean Sea, the respective general secretaries of the WCC, the Churches' Commission for Migrants in Europe (CCME) and the CEC jointly issued a comprehensive letter in which they called upon migrant-sending countries to address the aforesaid root causes of migration (WCC 2015: n.p.). This point was also reiterated at the WCC and UN conference on 20 January 2016 that called for coordinated efforts in addressing refugee crises. Such efforts include promoting principled 'human rights-based and coordinated responses to refugees and migrants in Europe and to the root causes of their displacement' (WCC 2016: n.p.). Although this shows that the WCC responds appropriately to migration challenges just like the UNHCR's approach, the former's response is rhetoric rather than action. Possibly, a coordinated response of the UNHCR and the church can effectively push the governments of refugee-sending nations to address the root causes of forced migration.

Having identified and discussed the UNHCR's interventions that meaningfully involve the churches in optimising its role 
in responding to refuge crises, I argue that there are key sticking issues that could be the barriers or challenges ${ }^{2}$ in preventing the integration of churches in the UNHCR's responses to migration crises or vice versa. However, the next article will focus on the barriers or challenges that prevent the integration of churches in the UNHCR's responses to migration crises or vice versa. In the final section is now discussed the existing opportunities for strengthening integrated UNHCR-Church interventions.

\section{Opportunities for strengthening integrated United Nations High Commissioner for Refugees-Church interventions}

In view of the discussion so far, I argue that there are many opportunities for strengthening integrated UNHCR-Church interventions.

Emerging from this discussion is the notion that most UNHCR and church interventions in refugee crises are similar. For instance, both organisations call on refugee-sending nations to address the root causes of mass migrations across international borders. Both entities are involved in the local integration of refugees in countries of first asylum and subsequent resettlement. In addition, the UNHCR and the church provide migrants and refugees with material support, human rights advocacy, upskilling and native language services. The last two interventions ease the process of socially and economically integrating refugees into the host countries.

The other intervention approaches to refugee crises that both the UNHCR and the church are involved in, include facilitating voluntary repatriation, as well as reintegration of returned refugees. As the international body mandated to protect refugees, forcibly displaced communities and stateless people and assist in their voluntary repatriation, local integration or resettlement in a third country, the UNHCR adheres to a comprehensive approach to intervention(UNHCR 2011b). As such, the UNHCR has the financial and human muscle to implement comprehensive interventions that require complex logistics. It is important to note, as indicated in the previous section, that the approach of many churches to intervention in refugee crises is hampered by a lack of financial and human resources (Goodall 2015:17-18; Kwinyani 2018:1417; Magezi 2018:284, 289-291).

Whilst I note the comprehensiveness of the UNHCR's interventions to refugee crises, I also subscribe to the WEF (2017:145) and Terfassa's conceptions (2016:189) that governments, institutions and NGOs cannot deal with the complex refugee issues alone. Instead, all the various stakeholders should work collaboratively to combat the

2.These barriers or challenges are the following: lack of thoroughly worked-out theologies of migration to drive the churches' migrant ministries, financial the churchis limitations, lack of clarification of the nature of the relationship between the church and the UNHCR's responses to refugee crises and, lastly, lack of understanding of legal barriers by the churches (cf. Adedibu 2016.263, Goodall 2015.17-18; Magez 2018:305-321; Magezi \& Mutowa 2018; Miles \& Villiers 2010:149-159; Mail \& Guardian 2010; UNHCR 2014:9) challenges of migration. This explains why the UNHCR involves refugee communities, civil society actors, government entities, other UN agencies and the church, as this ensures effective execution of its interventions (UNHCR 2019:1-3). Given this, the underlying question is as follows: What opportunities could be explored to strengthen integrated UNHCR-Church interventions?

In responding to this question, based on the discussion considered so far in this article, I suggest that the UNHCR should initially consider involving and integrating the church as a key player in addressing the refugee crisis. That is, instead of the church operating independently in responding to refugee crises, it could work alongside the UNHCR. However, this does not mean that there is no existing cooperation between the UNHCR and the faith-based communities. In many cases, there are formal working partnerships between the UNHCR and faith communities. For example, in December 2012 the UNHCR and the WCC formed a partnership to improve the protection of refugees (UNHCR 2014:6). The UNHCR (2014) confirms that:

[T]his was its first formal dialogue and partnership to ever engaged in and explored the common values underpinning the notion of refugee protection in all of the world's major religions. It also fostered deeper appreciation for and understanding of the role religion and spirituality plays in the lives of those UNHCR serves. (p. 6)

Unfortunately, this partnership is not perfect, as it has some inherent barriers that hinder the UNHCR from effectively integrating the churches in responding to migration crises some of which were highlighted in the previous section. Although I am cognisant of the existence of the UNHCRWCC partnership, there is need for more partnerships that are well regulated by all the parties concerned. This is critical, because the two entities could complement each other in strengthening their interventions in refugee crises. For instance, the UNHCR, as the international body responsible for protecting refugees, has greater potential than the church to raise financial resources - a portion of which can be given to the latter to meet the material needs (i.e. food and accommodation) of the refugees.

In view of the church's role in strengthening the interventions of the UNHCR, I argue as before in Magezi (2007:176) and Magezi (2017:4) that theology and the church are intricately linked to society and people's lives. Magezi (2007:176) rightly maintains that churches are subsystems of society (communities). In view of these realities, it is imperative for theology to reflect on practical life and societal issues such as migration. Furthermore, the church has been in the forefront in responding to social and community issues as clearly illustrated by Stark (1996) in his book, The rise of Christianity. The reality of the church as a community and social institution, and its theological content and tradition of care, challenges theology to play an active role in migration issues (Stark 1996). Thus, churches, as subsystems of societies, can assist the UNHCR to identify newly arrived refugees in both church and non-church spaces who require legal and material support from the 
UNHCR. Here, legal support refers to UNHCR-Church interventions for refugees in need of legal documentation such as asylum articles, as well as access to health, education, work and other rights that they are entitled to.

At this juncture, I argue that the role of the UNHCR is to capacitate churches with knowledge regarding the legal processes, requirements and procedures for applying for refugee or asylum status' in different countries. Such capacitation is crucial, because it equips the churches to be ready to assist refugees in need. Currently, the UNHCR and the church do not have much moral authority to call on the refugee-sending countries to address the root causes of migration without being practically involved themselves. Instead, the UNHCR and the church should establish formal collaborations that challenge refugee-sending nations to address the conflicts and human rights violations that result in large outflows of refugees. For example, whenever governments in the refugees' countries of origin need assistance to develop inclusive national policies to increase their capacity, the church and the UNHCR may participate in such processes to ensure that all the human-rights issues, enshrined in the international conventions on refugees and migration, are catered for to reduce the number of refugees across the globe.

Significantly, the UNHCR may also formally collaborate with the church in refugee-sending and host nations and so obtain leverage in efforts of the existing church to integrate migrants in the local communities and employment sectors. Currently, some churches are involved in upskilling migrants and teaching them the languages of host countries, although these efforts are hampered by limited financial and human resources. Given this, the UNHCR could collaborate with the church, which is a critical member of the community, to integrate refugees in the countries of asylum and resettlement, as well as reintegration upon repatriation to countries of origin. In substantiation, formal collaborations between the UNHCR and the church would enable the former to support the latter with financial and human resources to strengthen the integration of refugees.

\section{Conclusion}

This article identifies the UNHCR as the UN agency that is mandated to protect refugees, forcibly displaced communities, and stateless people through voluntary repatriation, local integration or resettlement to a third country. Notably, in performing its function, the UNHCR involves many stakeholders, such as the church, to ensure effective intervention. The question that emerges in such a complex issue as migration is how the UNHCR integrates the church in its approach to intervention, as some churches have evidently become the bulwarks of refugee safety in communities. The discussion in this article reveals that the approach of the UNHCR and that of most of the churches to refugee crisis. However, the UNHCR does more comprehensive interventions, as it has more financial muscle and human resources. With this in mind, I identified opportunities to strengthen the UNHCR-Church approach to intervention in refugee crises. For instance, among many other things, a formal UNHCR-Church collaboration is critical to strengthen their intervention in refugee crises, as the two institutions have complementary roles.

\section{Acknowledgements Competing interests}

There is not any financial or non-financial interest to the work described in the submitted manuscript.

\section{Author's contributions}

The author declares that they are the sole author of this research article.

\section{Ethical considerations}

This article followed all ethical standards for research without direct contact with human or animal subjects.

\section{Funding information}

This manuscript is funded by North-West University.

\section{Data availability}

Data sharing is not applicable for this article as no new data were created or analysed.

\section{Disclaimer}

The views and opinions expressed in this article are those of the author and do not necessarily reflect the official policy or position of any affiliated agency of the author.

\section{References}

Adedibu, B., 2016, 'Welcoming strangers! The responses of African Pentecostal churches in London to Europe's migration and refugee crisis', Missionalia 44(3) 263-283. https://doi.org/10.7832/44-2-173

Arrive Ministries, n.d., Churches responding to the global, refugee crisis, viewed 09 June 2020, from https://arriveministries.org/churches-responding-to-the-globalrefugee-crisis/.

Berkley Forum, 2018, How religious communities are responding to the refugee crisis, viewed 08 June 2020, from https://berkleycenter.georgetown.edu/posts/howreligious-communities-are-responding-to-the-refugee-crisis.

Bread for the World, 2016, World church leader offers ten commandments of food viewed 27 April 2020, from https://www.bread.org/blog/world-church-leaderoffers-ten-commandments-food.

Carling, J. \& Tallerra, C., 2016, Root causes and drivers of migration implications for humanitarian efforts and development cooperation, viewed 30 April 2020, from https://www.prio.org/Publications/Publication/?x=9229.

Chiba, H., 2016, 'The role of the Protestant Church in the US refugee resettlement program during the early cold war era', in M. Frederiks \& D. Nagy (eds.), Religion, migration and identity: Methodological and theological explorations, pp. 60-78, Leiden, Boston, MA.

Diocese of Southwark, 2015, Seeking the common good with a radical focus on Justice and kingdom values: Responding to the refugee crisis, viewed 08 June 2020, from https://southwark.anglican.org/downloads/resources/Refugees\%20booklet.pdf.

Fielden, A., 2008, Local integration: An under-reported solution to protracted refugee situations, UNHCR, viewed 02 June 2020, from https://www.unhcr.org/ 486cc99f2. pdf.

Gilmore, K., 2016, Keynote address: Side event 'Migrants in transit' by Deputy High Commissioner for Human Rights, viewed 02 June 2020, from https://www.ohchr. org/EN/NewsEvents/Pages/DisplayNews.aspx?NewsID=18485\&LangID=E.

Goodall, C., 2015, Shouting towards the Sky: The role of religious individuals, communities, organisations and institutions in support for refugees and asylum seekers, viewed 19 May 2020, from https://www.unhcr.org/research/ working/554764b49/shouting-towards-sky-role-religious-individualscommunities-organisations.html. 
Grandi, P., 2016, Solutions needed to stem global refugee crisis, says new UN agency, viewed 30 April2020, from https://www.unhcr.org/news/latest/2016/1/568e82ff6/ solutions-needed-stem-global-refugee-crisis-says-grandi.html.

ICMC/ProAsyl, 2013, A city says yes! Reflections on the experiences of the Save me campaign to promote refugee resettlement in Germany, viewed 06 May 2020, from https://www.resettlement.eu/page/city-says-yes-reflections-experiencessave-me-campaign-promote-refugee-resettlement-germany.

IOM, 2015, World migration report 2015 - Migrants and cities: New partnerships to manage mobility, viewed 12 August 2020, from https://publications.iom.int/ books/world-migration-report-2015-migrants-and-cities-new-partnershipsmanage-mobility.

Isphording, I.E., 2015, What drives the language proficiency of immigrants? Immigrants differ in their language proficiency along a range of characteristics, viewed 06 May 2020, from https://wol.iza.org/uploads/articles/177/pdfs/whatviewed 06 May 2020, from https://wol.iza.org/u
drives-language-proficiency-of-immigrants.pdf.

Jackson, D. \& Passarelli, A., 2016, Mapping migration, mapping churches' responses in Europe: Belonging, community and integration: The witness and service of churches in Europe, viewed 12 June 2020, from https://ccme.eu/wp-content/ uploads/2018/12/2016-01-08-Mapping_Migration 2015 Online lores_2_.pdf

Jacobsen, K., 2001, The forgotten solution: Local integration for refugees in developing countries, New Issues in Refugee Research, Working Paper No.45, UNHCR, Geneva, viewed 02 June 2020, from https://www.unhcr.org/research/ working/3b7d24059/forgotten-solution-local-integration-refugees-developingcountries-karen.html?query=Malawi.

Kuzituka, D.J.M., 2009, 'National identity and immigration from Africa: Relationships between Black South Africans and African Immigrants in Yeoville, Johannesburg', $M$ thesis, University of the Witwatersrand, Johannesburg.

Kwinyani, K., 2018, Monocultural churches in an age of migration, viewed 28 April 2020, from https://www.biblesociety.org.uk/content/explore the bible/bible in_transmission/files/2018_spring/Monocultural_churches_in_an_age_of_ migration.pdf

Magezi, C., 2017, 'Migration crisis and the church: A response to lacunae and considerations for Christian ministry engagement', Verbum et Ecclesia 38(1) a1671. https://doi.org/10.4102/ve.v38i1.1671

Magezi, V., 2007, HIV and AIDS, poverty and pastoral care \& counselling: A homebased and congregational systems ministerial approach in Africa, Sun Media, Stellenbosch.

Magezi, C., 2018, 'Theological understandings of migration and church ministry models: A quest for holistic ministry to migrants in South Africa', PhD thesis, North-West University, Potchefstroom

Magezi, V. \& Mutowa, C., 2018, 'Towards doing practical integral mission: A Nazarene Compassionate Ministries (NCM) reflection in Africa', Acta Theologica 38(2), 123-144.

Mail and Guardian, 2010, 'Paul Verryn: What went wrong?', Mail and Guardian, 29 January 2020, viewed 08 April 2020, from https://mg.co.za/article/2010-01-29paul-verryn-what-went-wrong/.

Mallows, D. (ed.), 2014, Language issues in migration and integration: Perspectives from teacher's learners, British Council, London.

Mckeon, N., 2018, Getting to the root causes of migration' in West Africa - Whose history, framing and agency counts?, viewed 30 April 2020, from https://www. tandfonline.com/doi/abs/10.1080/14747731.2018.1503842.

Miles, G. \& Villiers, I.D., 2010, 'Christian NGOS and their role in holistic mission', in B. Brian Woolnough \& W. Ma (eds.), Holistic mission: God's plan for God's people, pp.149-159, Regnum Books International, Oxford.

Nzayabino, V., 2010, 'The role of refugee-established churches in integrating forced migrants: A case study of Word of Life Assembly in Yeoville, Johannesburg', HTS Teologiese Studies/Theological Studies 66(1), Art. \#290, 1-9. https://doi. org/10.4102/hts.v66i1.290

Omidvar, R., 2016, The biggest issues facing migrants today and what we can do to solve them, World Economic Forum, viewed 30 April 2020, from https:// www.weforum.org/agenda/2016/11/the-biggest-issues-facing-migrantstoday/

Press Release No: 15/35, 2015, Refugee Crisis: Ecumenical Organisations Respond World Council of Churches, viewed 22 September 2020, from https://www. ceceurope.org/refugee-crisis-ecumenical-organisations-respond/.

Prill, T., 2009, 'Migration, mission and the multi-ethnic church', ERT 33(4), 332-346, viewed 28 April 2020, from https://www.researchgate.net/publication/ 283118771 Migration mission and the multi-ethnic church

Skeldon, R., 2013, Global migration: Demographic aspects and its relevance for development, Technical paper, No. 2013/6, viewed 28 April 2020, from https:// www.un.org/en/development/desa/population/migration/events/ expertgroup/2012/docs/UNNewYork-globmigpowerpoint_SH.pdf.

Stark, R., 1996, The rise of Christianity: How the obscure, marginal Jesus movement became the dominant religious force in the Western world in a few centuries, Princeton University Press, Princeton, NJ.

Stromberg, J., 2003, 'Responding to the challenge of migration: Churches within the Fellowship of the World Council of Churches (WCC)', Missiology: An International Review XXXI(1), 44-50. https://doi.org/10.1177/009182960303100107
Terfassa, D.O., 2016, 'Migration and inclusive community', in D. Field \& J. Koslowski (eds.). Prospects and challenges for the ecumenical movement in the 21st century: Insights from the global ecumenical theological institute, pp. 189-205, Insights from the global ecumethics.net Library, Geneva.

United Nations High Commissioner for Refugees (UNHCR), 2009, Solutions for refugees, viewed 19 May 2020, from https://www.unhcr.org/en-us/50a4c17f9.pdf.

United Nations High Commissioner for Refugees (UNHCR), 2011a, Guidance for public health interventions for repatriation, viewed 29 May 2020, from https://www. unhcr.org/4f7080349.pdf.

United Nations High Commissioner for Refugees (UNHCR), 2011b, UNHCR resettlement handbook, viewed 25 May 2020, from https://www.unhcr.org/46f7c0ee2.pdf.

United Nations High Commissioner for Refugees (UNHCR), 2014, Partnership note on faith-based organisations, local faith communities and faith leaders, viewed 28 January 2021, from https://www.unhcr.org/protection/hcdialogue $\% 20$ /539ef28b9/partnership-note-faith-based-organizations-local-faithcommunities-faith.html.

United Nations High Commissioner for Refugees (UNHCR), 2015, Global trends: Forced displacement in 2015, viewed 20 May 2020, from https://www.refworld. org/docid/57678f3d4.html.

United Nations High Commissioner for Refugees (UNHCR), 2016a, Evaluation of UNHCR's emergency response to the influx of Syrian refugees into Turkey, viewed 02 June 2020, from https://www.refworld.org/docid/58bd6e674.html.

United Nations High Commissioner for Refugees (UNHCR), 2016b, Syria conflict at 5 years: The biggest refugee and displacement crisis of our time demands a huge surge in solidarity, viewed 01 June 2020, from https://www.unhcr.org/news/ press/2016/3/56e6e3249/syria-conflict-5-years-biggest-refugee-displacementpress $/ 2016 / 3 / 56 e 6 e 3249 /$
crisis-time-demands.html.

United Nations High Commissioner for Refugees (UNHCR), 2017, Global trends: Forced displacement in 2016, viewed 20 May 2020, from https://www.unhcr.org/ statistics/unhcrstats/5943e8a34/global-trends-forced-displacement-2016.html.

United Nations High Commissioner for Refugees (UNHCR), 2018a, 2018 in review: Trends at a glance, reviewed 21 May 2020, from https://www.unhcr.org/ globaltrends2018/.

United Nations High Commissioner for Refugees (UNHCR), 2018b, Statement by UN high commissioner for refugees on the repatriation of Rohingya refugees to Myanmar, viewed 27 May 2020, from https://www.unhcr.org/news/press/2018/ $11 / 5$ be 7 c 4 b $64 /$ statement-un-high-commissioner-refugees-repatriationrohingya-refugees.html.

United Nations High Commissioner for Refugees (UNHCR), 2019, Update on UNHCR's operations in the Middle East and North Africa, viewed 27 May 2027, from https:// reliefweb.int/report/world/update-unhcr-s-operations-middle-east-and-northafrica-27-september-2019

United Nations High Commissioner for Refugees (UNHCR), 2020, Beware long-term damage to human rights and refugee rights from the coronavirus pandemic: UNHCR, viewed 01 June 2020, from https://www.unhcr.org/news/press/2020/ 4/5ea035ba4/beware-long-term-damage-human-rights-refugee-rightscoronavirus-pandemic.html.

United Nations (UN), 2016, Report of the Secretary-General - In safety and dignity: Addressing large movements of refugees and migrants (A/70/59), Seventieth Session, viewed 20 May 2020, from https://www.un.org/en/ga/search/view_doc. asp?symbol=A $/ 70 / 59 \&=E \% 20$.

United Nations (UN), 2019,Efforts to tackle global displacement crisis 'Fragmented', refugee agency chief tells security council, saying they address mere symptoms, not root causes, viewed 01 June 2020, from https://www.un.org/press/en/2019/ sc13770.doc.htm\#: :text=8504th\%20Meeting\%20(AM)-,Efforts\%20to\%20 Tackle\%20Global\%20Displacement $\% 20$ Crisis\%20'Fragmented'\%2C\%20 Refugee $\% 20$ Agency, Mere $\% 20$ Symptoms $\% 2$ C $\% 20$ Not $\% 20$ Root $\% 20$ Causes\&text=The\%20Council\%20can\%20help\%20to, and\%20remove\%20 obstacles\%2C\%20he\%20added.

Working Groups for the Syrian situation, 2019, Regional operational framework for refugee return to Syrian, viewed 29 May 2020, from https://reliefweb.int/report/ syrian-arab-republic/regional-operational-framework-refugee-return-syria.

World Economic Forum (WEF), 2017, Migration and its impact on cities, viewed 25 May 2020, from http://www3.weforum.org/docs/Migration_Impact_Cities_ report_2017_low.pdf.

World Council of Churches (WCC), 2011, Migration and migrant workers: Discerning responses as churches, viewed 23 April 2020, from https://www.oikoumene.org/ responses as churches, viewed 23 April 2020, from https://wWw.oikoumene.org/
resources/documents/migration-and-migrant-workers-discerning-responses-asresources/dc
churches.

World Council of Churches (WCC), 2015, A worldwide fellowship of churches seeking unity, a common witness and Christian service: The ecumenical movement in the
21st century, viewed 03 March 2020, from https://www.academia.edu/36047795/ A worldwide_fellowship_of_churches_seeking_unity_a_common_witness_and A Christian_service_The_ecumenical movement_in_the_21st_century.

World Council of Churches (WCC), 2016, WCC/UN conference calls for coordinated action on refugee crisis, WCC, viewed 23 April 2020, from https://www. oikoumene.org/news/wcc/un-conference-calls-for-coordinated-action-onrefugee-crisis.

World Council of Churches (WCC), 2017, Churches' advocacy for the rights of stateless people in Europe', World Council of Churches, viewed 22 April 2020, from https:// www.statelessness, eu/updates/blog/churches-advocacy-rights-stateless-peopleeurope. 